\title{
The Contribution of Portuguese Solar Thermal Program ON THE COUNTRY ENERGY EFFICIENCY
}

\author{
ANDREIA SALGUEIRO, JOÃo FARINHA MENDES
}

andreia.salgueiro@lneg.pt, farinha.mendes@lneg.pt

Laboratório Nacional de Energia e Geologia / Unidade Energia Solar, Eólica e dos Oceanos, Estrada Paço do Lumiar 22, 1649-038 Lisboa, Portugal.

ABSTRACT
The solar radiation available all over the year is a strong reason to promote the utilization of this resource and during
the year 2009, a new program based on a $50 \%$ subside, was promoted by the Portuguese government. As expected, a
significant number of new installations were realized. In 2009 the state program provided the installation of more than
50,000 systems. The program can be considered a success on the Portuguese solar thermal collector market.
SOLAR THERMAL GOVERNMENTAL PROGRAM

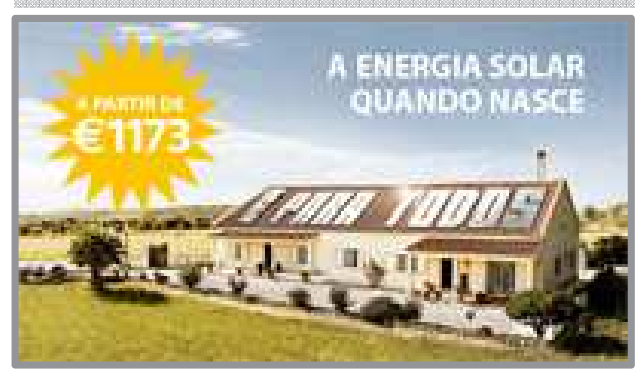

Initially the program was only for small systems. A set of characteristics were defined to cover all solutions. The relevant documentation of suppliers was verified by LNEG, who contributed also in the energy assessment for each solution using LNEG SolTerm software.

At the end of 2009 , the program was extended to associations with social mission, who chose the more convenient solution based on a ranked proposals according to solar fraction, technical characteristics and cost per $\mathrm{kWh}$, assuming a life time period of 20 years.

\section{GOVERNAMENTAL PROGRAM RESULTS}

Due to the great success of the program, not all the adjudicated systems $\left(176,000 \mathrm{~m}^{2}\right)$ were installed during 2009 , transferring to 2010 the installation of part of that area (Fig. 1)

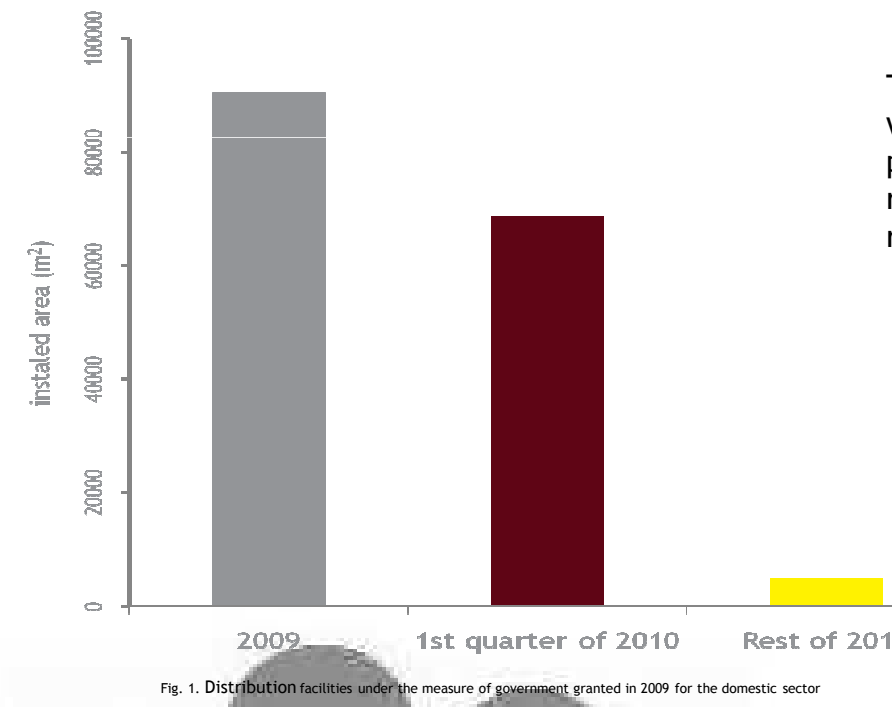

The Solar Thermal Program, was created in 2 March 2009 with 95 millions $€$. Almost $87 \%$ of the existing value for the program was allocated to residential systems and the remaining value was not enough for all applications (1358 requests) submitted by associations (Table 1 ).

Table 1. Total of orders/requests for private and associations under the encouraging solar thermal systems governmental measure.

\begin{tabular}{|c|c|c|c|}
\hline & Request & Area $\left(m^{2}\right)$ & Subsidy $(€)$ \\
\hline Private & 50,223 & 176,283 & $82,451,099.00 €$ \\
\hline \multirow[t]{2}{*}{ Associations } & 1,358 & 78,764 & $28,599,480.00 €$ \\
\hline & 51,581 & 255,047 & $110,050,579.00 €$ \\
\hline
\end{tabular}

\section{DEVELOPMENTS AND CONCLUSION}

The promotion of solar thermal energy, using governmental subsidies has proved a highly successful result. The budget of this measure allowed the atjudication of $176,000 \mathrm{~m}^{2}$ of solar collectors, in 2009, doubling the facilities installed during the previous year (Fig, 2). In early 2010 it was not sure that the measure would continue, but recently 9.5 million€ were made available until October $15^{\text {th }}$ 2010. The result of these measures was the development of a strong solar collector market in Portugal. Although limited at the subsidy side, those measures being kept in 2010, complemented with the mandatory installation of solar collectors in all new buildings, are providing a base for the sustainable development of this market.

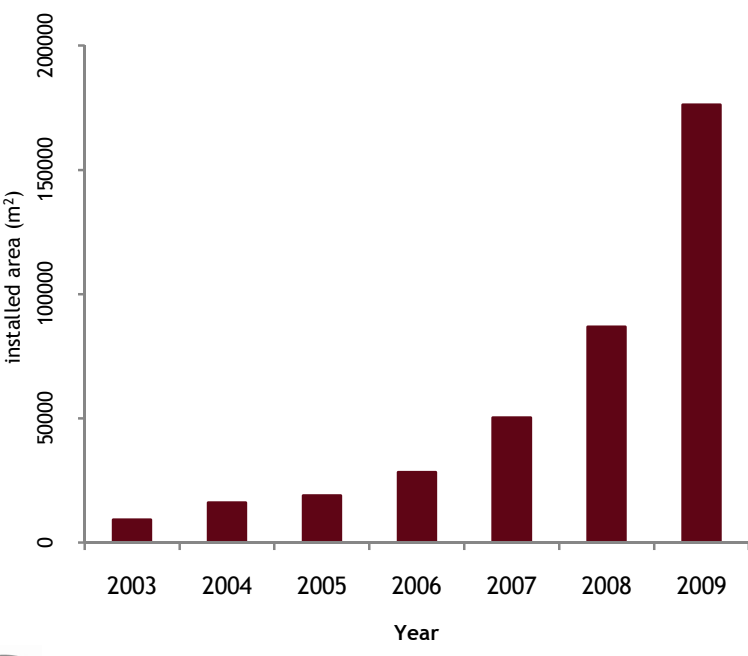

Fig. 2. Evolution of solar thermal collectors market in Portugal 